\title{
SPECIES OF CONTRACAECUM PARASITIZING THE MAGELLANIC PENGUIN SPHENISCUS MAGELLANICUS (SPHENISCIDAE) FROM THE ARGENTINEAN COAST
}

\author{
Lucas E. Garbin ${ }^{1 *}$, Julia I. Diaz ${ }^{2 *}$, and Graciela T. Navone ${ }^{2}$ \\ 1 Sección Ornitología, División Zoología Vertebrados, Facultad de Ciencias Naturales y Museo (UNLP-CONICET), La Plata, Buenos Aires, Argentina. \\ ${ }^{2}$ Centro de Estudios Parasitológicos y de Vectores (CCT La Plata-CONICET-UNLP), Facultad de Ciencias Naturales y Museo, Universidad Nacional de La Plata \\ (UNLP), calle 120 e/61 y 62, B1900FWA La Plata, Buenos Aires Province, Argentina. \\ * These authors contributed equally to this work. \\ Correspondence should be sent to Lucas E. Garbin at: Igarbin@fcnym.un/p.edu.ar
}

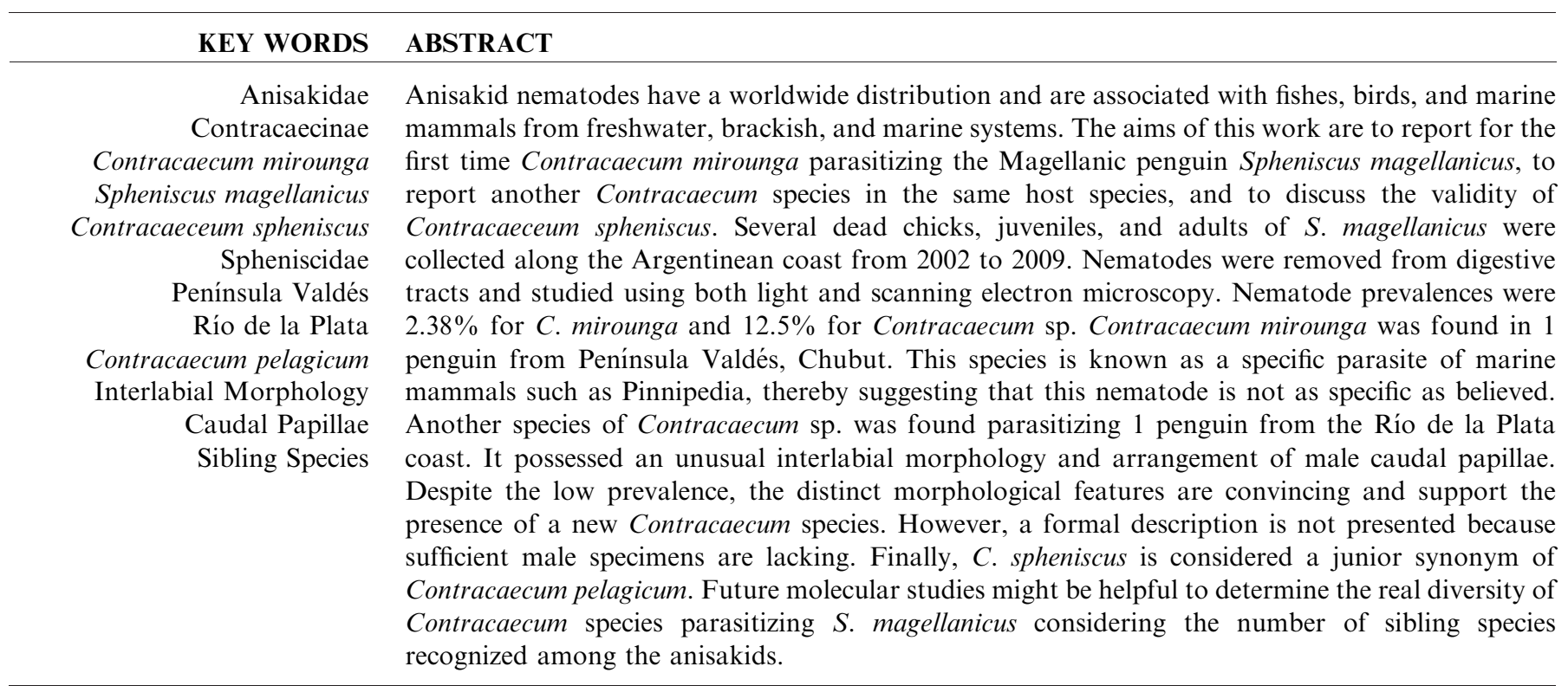

Anisakid nematodes have a worldwide distribution and are associated with freshwater, brackish, and mainly marine systems. Transmission of species usually involves aquatic invertebrates and fishes as intermediate or paratenic hosts and piscivorous birds and mammals as definitive hosts (e.g., cormorants, pelicans, and seals [Anderson, 2000; Rohde, 2005]). Within Anisakidae, the genus Contracaecum Raillet and Henry parasitizes fish-eating birds and marine mammals around the world. Most Contracaecum species seem to have little host specificity, e.g., Contracaecum pelagicum Johnston \& Mawson, 1942, Contracaecum microcephalum (Rudolphi, 1809), and Contracaecum rudolphii (Hartwich, 1964) exhibit low host specificity and parasitize bird hosts of different orders. However, cases of strict specificity exist such as in the case of Contracaecum osculatum baicalensis Moszgovoi and Ryzhykov, 1950 parasitizing only the Baikal seal Phoca sibirica Gmelin (Phocidae) (Mattiucci and Nascetti, 2008).

In Argentina, 7 Contracaecum species have been reported to date; C. microcephalum (Rudolphi, 1809) and Contracaecum multipapillatum (von Drasche, 1882) were registered in different species of Ardeidea (Schuurmans Sterkhoven, 1951; Boero et al., 1972; Labriola and Suriano, 1996; Navone et al., 2000). Contracaecum travassosi Gutiérrez, 1943 and Contracaecum chubutensis Garbin, Diaz, Cremonte and Navone, 2008 were reported from the imperial shag Phalacrocorax atriceps Lesson (Phalacrocoracidae) (Gutiérrez, 1943; Garbin et al., 2008). Contracaecum australe Garbin, Mattiucci, Paoletti, González-Acuña, and Nascetti, 2011 parasitizes the Neotropical cormorant Phalacorcorax brasilianus Gmelin and the red-legged cormorant Phalacrocorax gaimardi (Lesson and Garnot) (Garbin et al., 2011, 2014; Biolé et al., 2012).

In the case of the Magellanic penguin Spheniscus magellanicus Forster, there are 2 records; Contracaecum spheniscus Boero and Led, 1971 was described on the basis of a single juvenile male specimen found in 1 adult penguin from La Plata Zoo, Buenos Aires Province, Argentina (Boero and Led, 1971), and $C$. pelagicum was reported and redescribed from $S$. magellanicus 


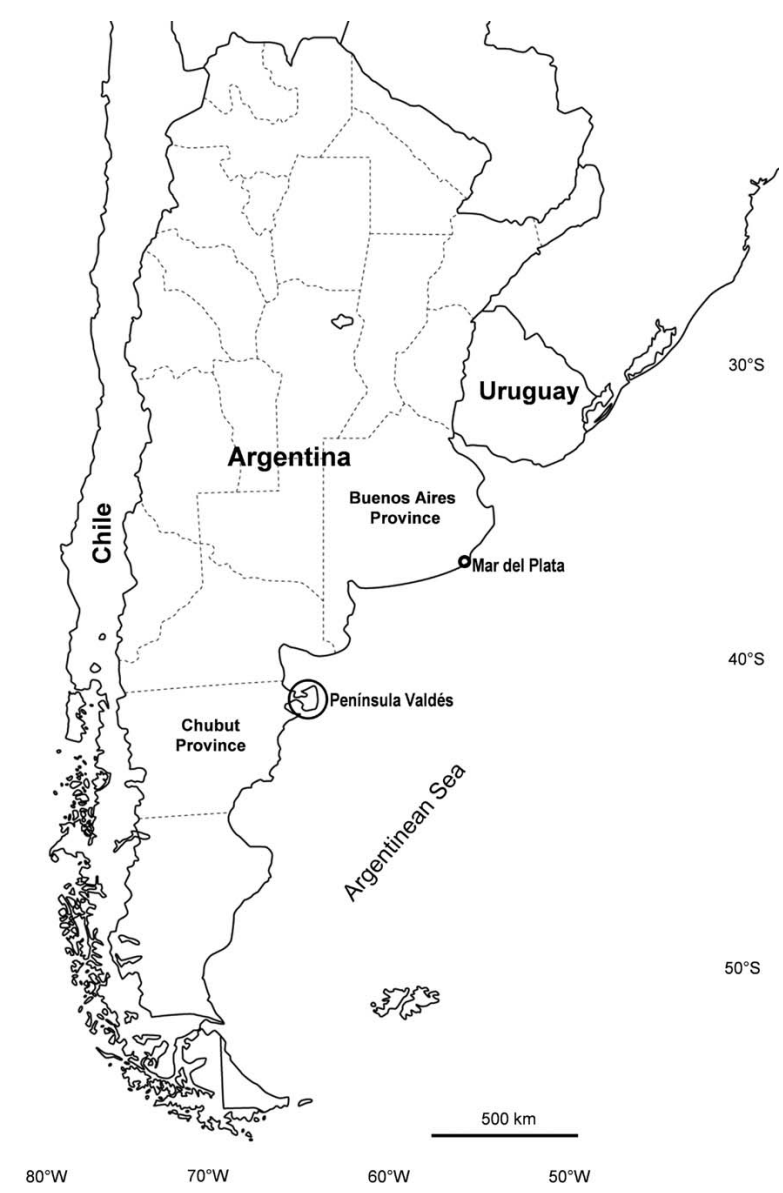

Figure 1. Sampling sites on the Argentinean coast.

from the Península Valdés coast, Chubut Province and Mar del Plata coast, Buenos Aires Province (Diaz, 2006; Garbin et al., 2007; Diaz et al., 2010). This species also was reported in the black browed albatross Talassarche melanophris (Temminck) and in $P$. atriceps from the Chubut coast (Garbin et al., 2007, 2013). Later, Garbin et al. (2013) characterized, using molecular data and morphology, C. pelagicum from $S$. magellanicus, and corroborated its transmission by the anchovy Engraulis anchoita in the North Patagonian Sea.

On the basis of this aforementioned background, the aims of this work are: (1) to report for the first time Contracaecum mirounga Nikolskiy, 1974 in 1 S. magellanicus adult from Península Valdés, Chubut Province; (2) to report a Contracaecum species parasitizing $1 \mathrm{~S}$. magellanicus adult from the Río de la Plata coast, Buenos Aires Province; and (3) to discuss the validity of C. spheniscus.

\section{MATERIALS AND METHODS}

At intervals between May 2002 and May 2009, 139 dead chicks, juveniles, and adults of $S$. magellanicus were collected along the Argentinean coast: 131 from Península Valdés, Chubut Province coast $\left(42^{\circ} 04^{\prime}-42^{\circ} 53^{\prime} \mathrm{S}, 63^{\circ} 38^{\prime}-64^{\circ} 30^{\prime} \mathrm{W}\right), 7$ from Buenos Aires Province coast $\left(35^{\circ} 26^{\prime} \mathrm{S}-57^{\circ} 7^{\prime} \mathrm{W}, 41^{\circ} 02^{\prime} \mathrm{S}-62^{\circ} 48^{\prime} \mathrm{W}\right)$ (Fig. 1). Penguins were dissected and their digestive tracts were fixed in $10 \%$ formalin. The proventriculus and esophagus were examined using a stereomicroscope. Nematodes were removed and stored in $70 \%$ ethanol. Additionally, authors had access to some nematode specimens extracted from 1 dead $S$. magellanicus from La Plata Zoo, stranded on an unknown site on the Río de la Plata coast, Buenos Aires Province.

Nematodes were cleared in lactophenol and studied with light microscopy (LM) using an Olympus BX51 ${ }^{\circledR}$ (Olympus, Tokyo, Japan) microscope. Drawings were made with the aid of a drawing tube. Some specimens were processed for scanning electron microscopy (SEM), dried by the critical point method, and observed using a JEOL/JSMT 6360 LV $^{\circledR}$ scanning electron microscope (JEOL Ltd., Tokyo, Japan). Mean measurements are expressed in millimeters with the range in parentheses. The arrangement of male caudal papillae was described according to the terminology of Fagerholm (1988, 1990, 1991), except that of the distal postcloacal papillae to better differentiate them spatially. Prevalence of infection was calculated for both Contracaecum species according to Bush et al. (1997).

\section{DESCRIPTION}

\section{Contracaecum mirounga Nikolskiy, 1974}

(Figs. 2, 3A-C; Tables I, II)

General description (on the basis of 5 males and 8 females from $S$. magellanicus observed with SEM and LM): Body entirely transversely striated (Fig. 2A-F). Apical lips with central keel inside shallow notch (see upper black arrow) and 2 auricles bearing tiny terminal sensory tips (Fig. 2A-C). Dorsal lip bearing pair of double labial papillae, 1 pair of subventrals plus single small amphid (Fig. 2A-C). Three triangular entire nonbifurcated interlabia shorter than lips (Fig. 2B, C). Cephalic collar with concentric free edges and a $\mathrm{v}$-shaped lateral region without striations (Figs. 2A-C, 3A). Round and conspicuous deirids (Fig. 2A, lower black arrow). Ventriculus with posterior appendix, intestinal cecum well developed (Fig. 3A).

Male: Conical flat caudal end bearing 68 to 74 precloacal papilla pairs (Figs. 2D, E, 3B). Precloacal transverse striae (PTS) zone comprising 11-12 proximal precloacal papillae (Figs. 2D, E, 3B) arranged in double and even triple rows starting from level of cloaca (Figs. 2D-F, 3B). Five to 6 proximal papillae-adacloacals - situated posterior to cloaca (Figs. 2D-F, 3B). Paracloacal papillae associated with cloaca: 1 double subventral postparacloacal papilla, and median preparacloacal papilla or plaque (Figs. 2D-F, 3B). Four subterminal papillae grouped as 3 subventrals in tandem, and only 1 sublateral (Figs. 4D, F, 3B). One phasmid placed more dorsally next to sublateral papilla on posterior half of the tail (Figs. 2D, F, 3B, see arrows). Both spicules similar in length (Table I). Caudal end with pointed tip (Fig. 3B).

Female: Vulva in anterior half of body, on average of one-third from anterior end. Embryonated eggs almost spherical (Table II). Tail conical pointed tip (Fig. 3C). Papillate phasmids situated sublaterally on tail.

\section{Taxonomic summary}

Type host: Mirounga leonina Linnaeus, 1758 (Mammalia, Phocidae).

Other known hosts: Spheniscus magellanicus Foster, 1781 (Aves, Spheniscidae). 


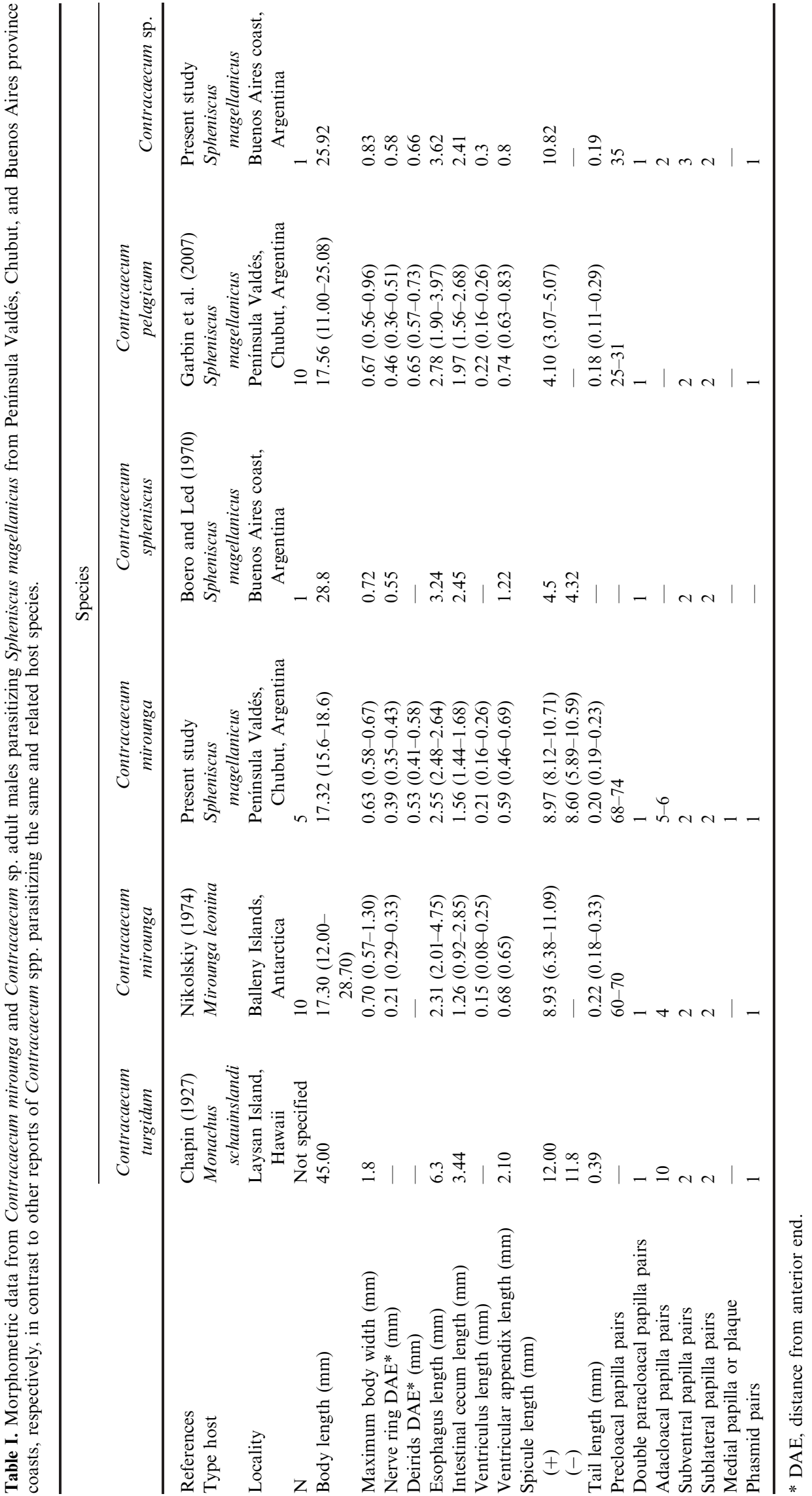



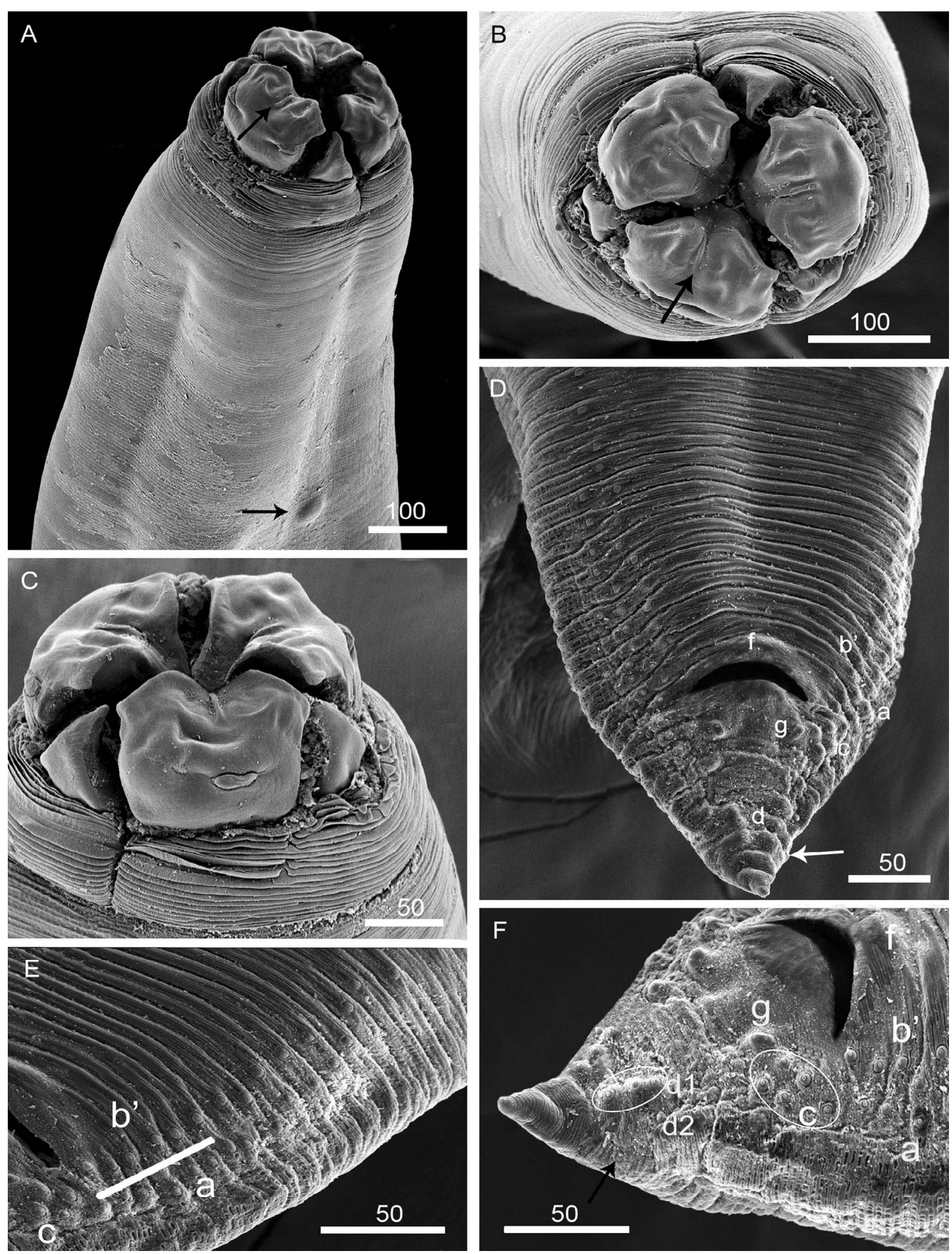

Figure 2. Scanning electron micrographs of Contracaecum mirounga Nikolskiy, 1974 parasitizing Spheniscus magellanicus from Península Valdés coast, Chubut Province. (A) Anterior end, lateral view; note dorsal lip, auricles with sensory tips, central keel on shallow notch (upper black arrow), labial papillae, entire interlabia, cephalic collar, deirids (lower black arrow). (B) Anterior end, subdorsal view; note lips, auricles with sensorial tips, central keel on shallow notch (black arrow), labial papillae, interlabia. (C) Anterior end, lateral view; note lateroventral lip, labial papilla, amphid, interlabia, cephalic collar with a v-shaped lateral region. (D) Male posterior end, subventral view; note post- and precloacal papillae, phasmid (white 
Type locality: Balleny Islands, Antarctica $\left(66^{\circ} 55^{\prime} \mathrm{S}, 163^{\circ} 45^{\prime} \mathrm{W}\right)$. Other localities: Península Valdés, Chubut Province, Argentina $\left(42^{\circ} 04^{\prime}-42^{\circ} 53^{\prime} \mathrm{S}, 63^{\circ} 38^{\prime}-64^{\circ} 30^{\prime} \mathrm{W}\right)$.

Site of infection: Proventriculus.

Prevalence: $2.38 \%$ (1 of 42 adult penguins examined).

Specimens deposited: Helminthological Collection of Museo de La Plata (MLP-He 7464), Buenos Aires, Argentina.

\section{Remarks}

The present specimens found in a single $S$. magellanicus adult from Península Valdés were identified as $C$. mirounga on the basis of the morphometric analysis and arrangement of male caudal papillae. However, no significant differences were observed when comparing the present specimens with those described in the original description of Nikolskiy (1974).

Contracaecum mirounga is very similar to Contracaecum turgidum Chapin, 1927. However, both males and females of $C$. mirounga are significantly smaller than $C$. turgidum (Tables I, II) (Chapin, 1927). Additionally, C. mirounga males differ from $C$. turgidum by having smaller spicules: 8.93 (6.38-11.09) vs. 12.00 $\mathrm{mm}$, and a lower number of adacloacal papillae (5-6 vs. 10). Besides, proximal precloacal papillae on the PTS zone are more crowded in $C$. mirounga, being arranged in double or even triple columns (Fig. 2D-F; Table I) (Chapin, 1927; Fagerholm, 1988). On the other hand, C. turgidum parasitizes phocids such as the endemic Hawaiian monk seal Monachus schauinslandi Matschie (Chapin, 1927; Fagerholm et al., 1988).

Contracaecum sp.

(Figs. 3D-F, 4; Tables I, II)

Description (on the basis of 1 male and 3 females from $1 S$. magellanicus observed with SEM and LM): Body entirely transversely striated (Fig. 4A-D). Lips without notches, with 2 prominent lobed auricles and well-remarkable sensory tips (Fig. 4A, B). Conspicuous labial papillae, 2 on dorsal lip, 1 on each ventrolateral lip with 1 small amphid (Fig. 4A, B). Three entire and well-developed interlabia with a biconcave apex (Fig. 4A, B, see black arrows). Well-developed, thick, and conspicuous cephalic collar with about 20 deep concentric free edges, and a v-shaped lateral region without striations (Figs. 3D, 4A, B). Round and conspicuous deirids. Ventricle with a regular appendix, intestinal cecum well developed (Fig. 3D).

Male: Conical caudal end bearing 35 pairs of conspicuous precloacal papillae, slightly raised, mammiform (Figs. 3E, 4C, D). PTS zone comprising 4 proximal pairs of precloacal papillae (Figs. 3E, 4D). Two proximal postcloacal papillae - adacloacallocated below the level of the cloacal commissures (Figs. 3E, 4D). Paracloacal papillae associated with cloaca: 1 double pair of postparacloacal papillae located just below lower cloacal commissures (Figs. 3E, 4D, F). Paracloacal median papilla or plaque not seen. Five pairs of subterminal papillae grouped as 3 subventral, and 2 sublateral ones. One phasmid placed more ventrally between these latter 2 papillae (Figs. 3E, 4D, F). Both spicules similar in length reaching almost half of body (Table I).
Sharply pointed spicule tip with very short free distal end $(23 \mu \mathrm{m})$ (Fig. 4C, E). Conical caudal end with a sharply pointed tip (Fig. $4 \mathrm{C}, \mathrm{E})$.

Female: Tail conical with blunt tip. Wide cloacal opening. Papillate phasmids situated sublaterally on tail (Fig. 3F). Vulva in anterior half of body. Embryonated eggs almost spherical (Table II).

\section{Taxonomic summary}

Type host: Spheniscus magellanicus Foster, 1781 (Aves, Spheniscidae).

Type locality: Unknown site on the Rio de la Plata coast, Buenos Aires Province, Argentina $\left(35^{\circ} 26^{\prime} \mathrm{S}-57^{\circ} 7^{\prime} \mathrm{W}\right.$ to $41^{\circ} 02^{\prime} \mathrm{S}-$ $\left.62^{\circ} 48^{\prime} \mathrm{W}\right)$.

Site of infection: Proventriculus.

Prevalence of infection: $12.5 \%$ ( 1 of 8 penguins examined from the Buenos Aires coast).

Specimens deposited: Helminthological Collection of Museo de La Plata (MLP-He 7465), Buenos Aires, Argentina.

\section{Remarks}

In certain aspects of their morphology, the present specimens are very different from the other observed Contracaecum species and this morph does not appear to have been described previously. None of the described Contracaecum species shows the unusual interlabia with a biconcave apex (Fig. 4A, B, see black arrows). Usually, Contracaecum interlabia are either entire or bifid. Another peculiar feature is the conspicuous, thick, and robust cephalic collar not seen in other Contracaecum spp., particularly those numerous concentric deep free edges (Figs. 3D, 4A, B). The pattern (distribution) of male postcloacal papillae studied here is unique since it is not shared by any other known Contracaecum species. The arrangement of caudal papillae in Contracaecum spp. falls within 4 different morphotypes: $C$. osculatum type, C. mirounga/turgidum type, C. radiatum type, and $C$. ogmorhini type (Fagerholm, 1988). The 3 first types are commonly found in Contracaecum spp. parasitizing pinnipeds. The latter type is typical of piscivorous birds and consists of 1 double pair of postparacloacal papillae, 2 distal subventral pairs, 2 distal sublateral pairs, and 1 pair of phasmids such as in $C$. ogmorhini (Fagerholm, 1988). However, the specimen studied here does not match any of the 4 morphotypes discussed by Fagerholm (1988). It looks like the C. mirounga/turgidum type due to the presence of 3 distal subventral papilla pairs but the proximal precloacal caudal papillae and the adacloacal ones are less numerous (Fagerholm, 1988). Neither does the papilla arrangement match that of the $C$. ogmorhini type since it exhibits a greater number of papillae such as 1 extra subventral one and 2 adacloacal ones (Fagerholm, 1988).

When comparing present specimens with other Contracaecum species parasitizing $S$. magellanicus, some morphometric characters overlap those of the following species: $C$. pelagicum and $C$. spheniscus (Boero and Led, 1971; Portes-Santos, 1984; Garbin et al., 2007) (see Tables I, II). Nevertheless, present specimens

arrow). (E) Male posterior end, sublateral view. (F) Male posterior distal end, subventral view; note phasmid (black arrow) (a, precloacal transverse striae (PTS) zone; $\mathbf{b}^{\prime}$, proximal precloacal caudal papillae; c, adacloacal papillae; d, distal caudal papillae; d1, subventral papillae; d2, sublateral papilla; f, median papilla or plaque; $\mathbf{g}$, double postparacloacal papillae.) 


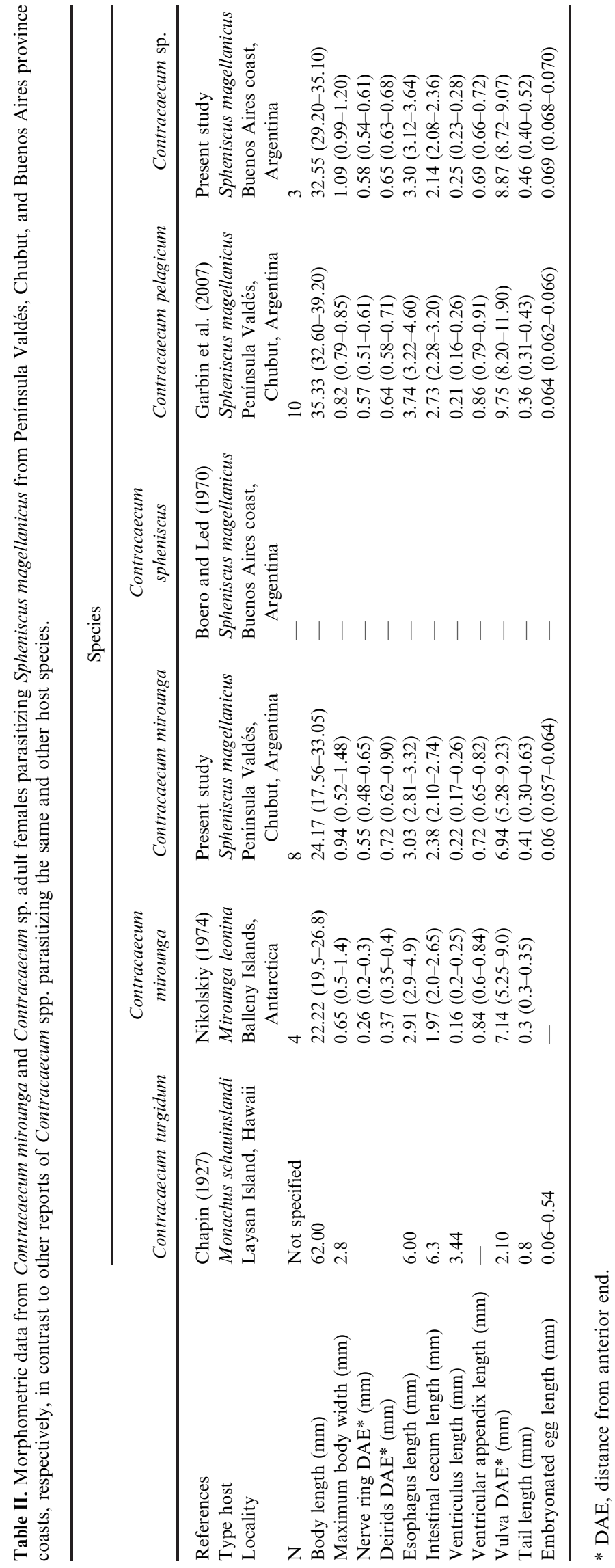

exhibit marked differences in their interlabial morphology and distribution of male caudal papillae compared with Contracaecum species mentioned above.

\section{DISCUSSION}

Previous studies have reported only specimens of $C$. pelagicum from this host and it is the most common worm in this bird species (Portes-Santos, 1984; Garbin et al., 2007; Diaz et al., 2010; Novo Borges et al., 2014). On the other hand, C. pelagicum exhibits low host specificity since it can parasitize different bird orders (Silva et al., 2005; Garbin et al., 2007, 2013; Garbin, 2009). Our study adds to the host-parasite associations of Contracaecum spp. and documents the presence of other Contracaecum spp. in Magellan's penguins.

Contracaecum mirounga differs from the other multipapillate congeners parasitizing pinnipeds (e.g., C. osculatum, C. turgidum, and $C$. radiatum), highlighting the relevance of the caudal papilla pattern in the taxonomy of the genus Contracaecum (Fagerholm et al., 1988). The report of C. mirounga parasitizing only 1 penguin from Península Valdés in the present study is noteworthy. However, it would not be rare considering that $S$. magellanicus overlaps the same foraging area and prey items (e.g., the squids Loligo spp. and Illex spp.) of the elephant seal, $M$. leonina, and the South American fur seal Arctocephalus australis (Zimmermann), habitual hosts of C. mirounga (Mattiucci et al., 2003, 2008b; Lewis et al., 2006; Campagna et al., 2007). Therefore, either this nematode species parasitizes penguins with low prevalence and can utilize it as an adequate definitive host, or this constitutes an accidental infection in penguins. The presence of mature nematodes suggests that $S$. magellanicus constitutes a suitable definitive host and that the nematode is not as specific as previous studies would indicate.

The finding of a previously undescribed morphotype, Contracaecum sp., in only 1 penguin from the Buenos Aires provincial coast is noteworthy because errant $S$. magellanicus penguins are usually found on this coast; some penguins die or are taken to aquariums or zoos (García-Borboroglu and Boersma, 2015). The parasitized penguin could have acquired this rare parasite by ingesting an uncommon prey item during migration to and from the southern coast of Brazil in the winter. Another, more feasible, hypothesis is that the penguin could have ingested an unusual prey item infected with Contracaecum sp. larvae by feeding at the zoo. New findings and morphological studies on a larger number of specimens can test this hypothesis. The morphological features described above are convincing and would support the description of a new species according to the unusual arrangement of male caudal papillae and interlabial shape never seen in other known Contracaecum species. However, sufficient specimens weren't available to justify a formal description. If this were possible, a new and fifth Contracaecum morphotype might be proposed that bears 4 proximal precloacal caudal papilla pairs comprised by the PTS zone, 2 proximal postcloacal papilla pairs adacloacal, 1 double postparacloacal pair, 3 distal subventral pairs, 2 sublateral pairs, and 1 phasmid pair.

Finally, according to the morphometric features of the unique C. spheniscus specimen described and drawn by Boero and Led (1971), which was not deposited in any reference collection, we believe that it belongs to a juvenile male of C. pelagicum (Table I). 


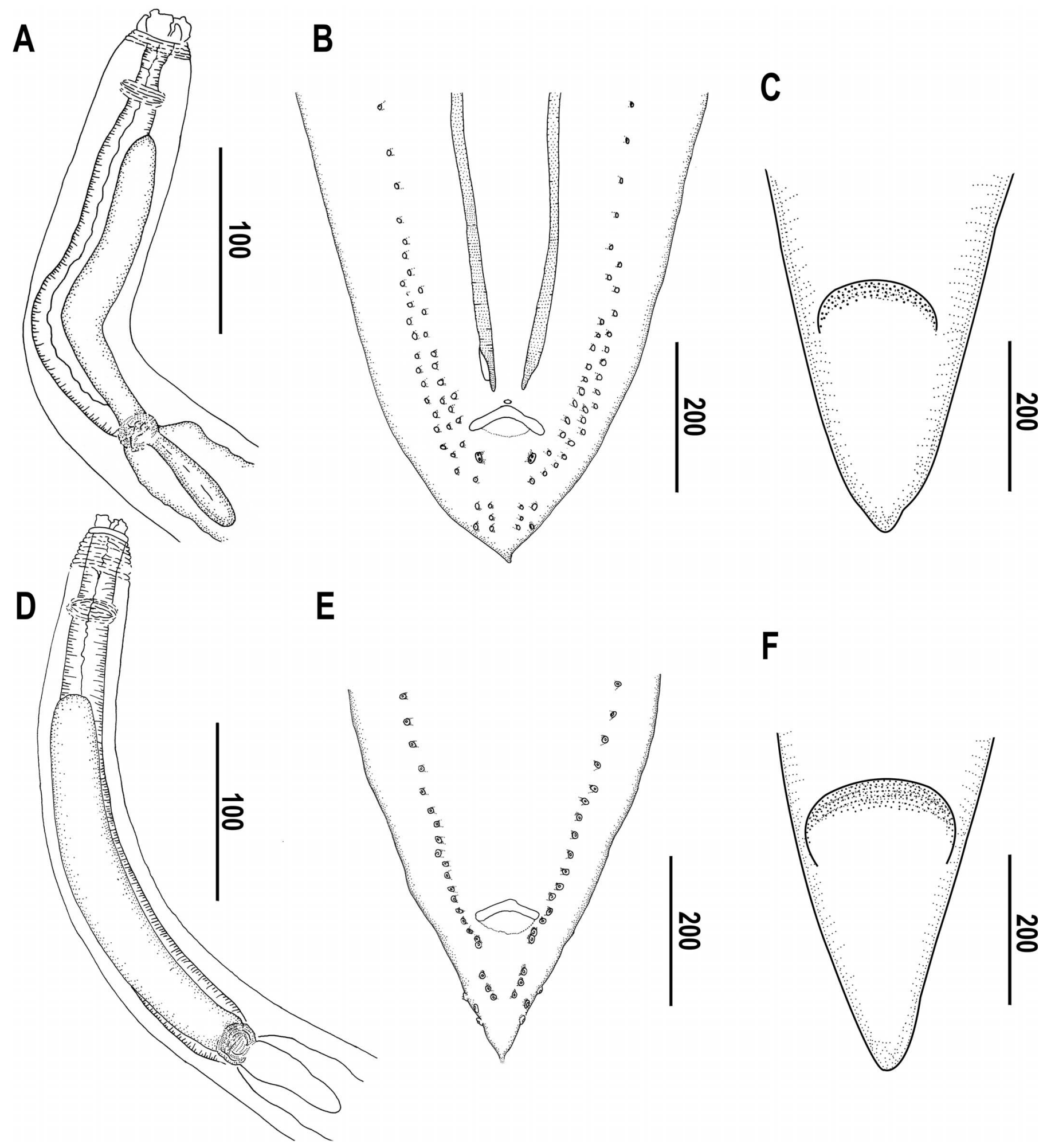

Figure 3. (A-C) Drawings of Contracaecum mirounga Nikolskiy, 1974 parasitizing Spheniscus magellanicus from Península Valdés coast, Chubut Province. (A) Anterior end, lateral view; note lips, cephalic collar, nerve ring, esophagus, intestinal cecum, ventriculus, ventricular appendix. (B) Posterior male end; note pre- and postcloacal papilla distribution, spicules, cloaca. (C) Posterior female end; note cloaca. (D-F) Drawings of Contracaecum sp. parasitizing Spheniscus magellanicus from the Buenos Aires Province coast. (D) Anterior end, lateral view; note lips, cephalic collar, nerve ring, esophagus, intestinal cecum, ventriculus, ventricular appendix. (E) Posterior male end; note pre- and postcloacal papilla distribution, cloaca. (F) Posterior female end; note cloaca. 

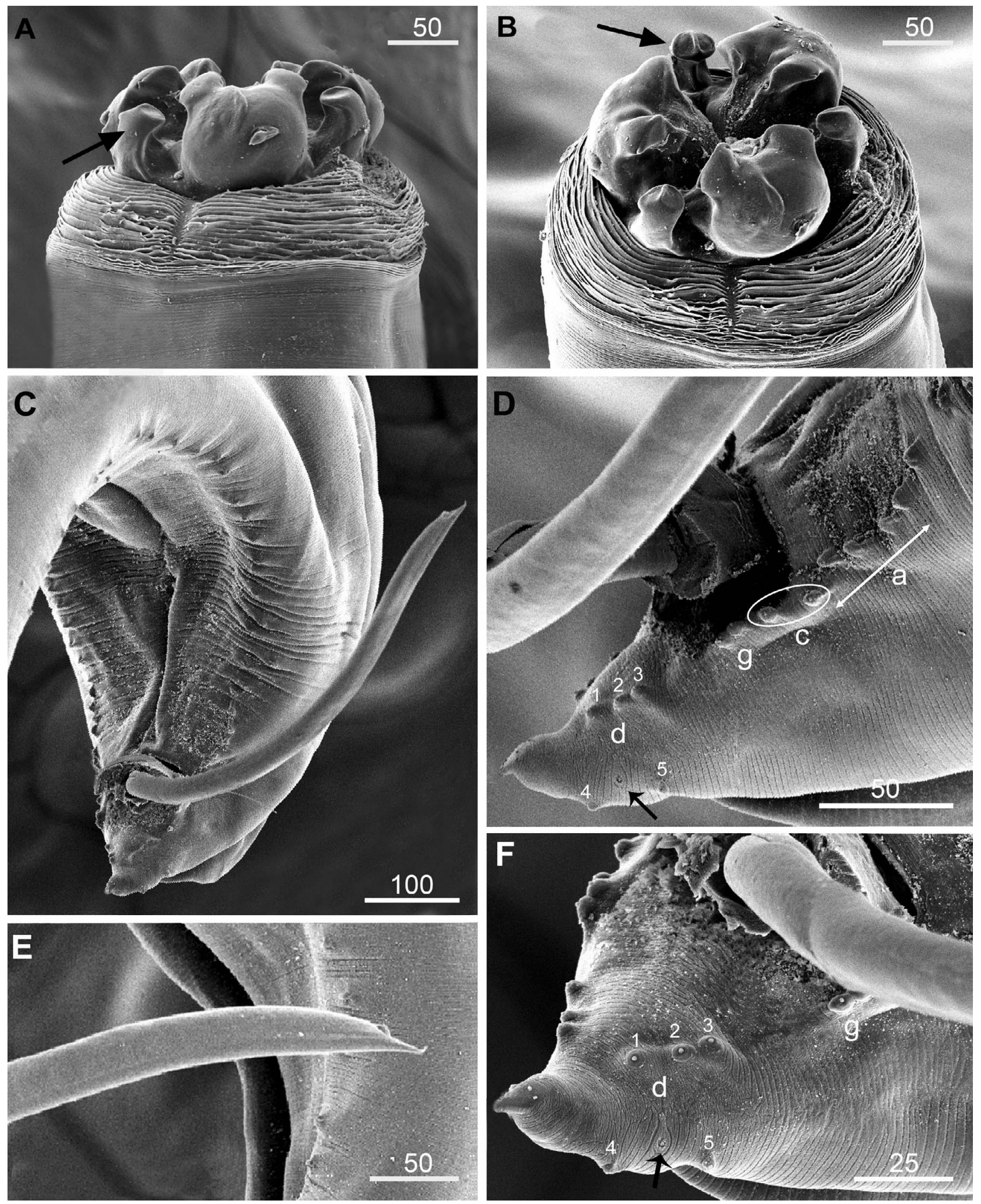

Figure 4. Scanning electron micrographs of Contracaecum sp. parasitizing Spheniscus magellanicus from the Buenos Aires Province coast. (A) Anterior end, lateral view; note lateroventral lip, lobed auricles with sensory tips, labial papilla, interlabium with a biconcave apex (black arrow), cephalic collar with a v-shaped lateral region. (B) Anterior end, laterodorsal view; note lateroventral lip, lobed auricles with sensory tips, labial papilla, interlabium with a biconcave apex (black arrow), cephalic collar with a v-shaped lateral region. (C) Male posterior end, note spicule, post- and precloacal papillae, cloaca. (D) Male posterior end. (E) Detailed distal spicule end. (F) Male posterior distal end (a, precloacal transverse striae zone with proximal precloacal caudal papillae; c, adacloacal papillae; d, subterminal papillae, subventrals $[1,2,3]$, sublaterals $[4,5]$, phasmids [black arrow]; g, double postparacloacal papilla.) 
For this reason, we propose $C$. spheniscus as a junior synonym of C. pelagicum.

In the future, molecular studies could be helpful to determine the real diversity of Contracecum species parasitizing S. magellanicus, taking into account the large number of sibling species currently recognized among the Anisakidae.

\section{ACKNOWLEDGMENTS}

We are grateful to Dr. Florencia Cremonte for providing us the facilities of the Laboratorio de Parasitología (IBIOMARCENPAT) to analyze most bird samples. Also, we thank Dr. Diego Montalti for his contribution to penguin ecology. This research was funded by the Consejo Nacional de Investigaciones Científicas y Técnicas (PIP 0698), Universidad Nacional de La Plata (UNLP N758, N859), and Agencia Nacional de Promoción Científica y Tecnológica (PICT 309).

\section{LITERATURE CITED}

Anderson, R. C. 2000. Nematode parasites of vertebrates. Their development and transmission, 2nd ed. CABI Publishing, Farnham Royal, U.K., 650 p.

Biolé, F. G., E. G. Silvia, M. A. Mancini, R. D. Tanzola, V. Salinas, and G. Morra. 2012. Primer registro de Contracaecum australe (Nematoda: Anisakidae) en Phalacrocorax brasilianus (Aves: Phalacrocoracidae) de la región central de Argentina. BioScriba 5: 1-11.

Boero, J. J., AND J. E. Led. 1971. El parasitismo de la fauna autóctona. V. Los parásitos de las aves argentinas. VI. Los parásitos de los ofidios argentinos. VII. Los parásitos de los murciélagos argentinos. Analecta Veterinaria 3: 91-103.

Boero, J. J., J. E. Led, AND E. Brandetti. 1972. El parasitismo de la fauna autóctona. Revista de Agronomía y Veterinaria 1: $17-29$.

Bush, A. O., K. D. Lafferty, J. M. Lotz, and A. W. Shostak. 1997. Parasitology meets ecology on its own terms: Margolis et al. revisited. Journal of Parasitology 83: 575-583.

Campagna, C., A. R. Piola, M. R. Marin, M. Lewis, U. Zajaczkovisi, and T. Fernández. 2007. Deep divers in shallow seas: Southern elephant seals on the Patagonian shelf. Deep-Sea Research Part I 54: 1792-1814.

Chapin, E. A. 1927. Descriptions of new internal parasites. Proceedings of the U.S. National Museum 68: 1-4.

DiAz, J. I. 2006. Las comunidades parasitarias como expresión de distinto comportamiento trófico en aves del Mar Argentino. Ph.D. Dissertation. FCNyM, National University of La Plata, Buenos Aires, Argentina, 259 p.

Diaz, J. I., F. Cremonte, and G. T. Navone. 2010. Helminths of the Magellanic penguin, Spheniscus magellanicus (Sphenisciformes), during the breeding season in Patagonian coast, Chubut, Argentina. Comparative Parasitology 77: 172-177.

Fagerholm, H. P. 1988. Patterns of caudal papillae in Contracaecum osculatum (Nematoda) and some related species from different regions of the world. International Journal for Parasitology 18: 1039-1051.

Fagerholm, H. P. 1990. Systematic position and delimitation of ascaroid nematode parasites of the genus Contracaecum with a note on the superfamily Ascaridoidea. Ph.D. Dissertation. Department of Biology, Abo and National Veterinary Institute, Helsinki, Finland, 127 p.
FAgerholm, H. P. 1991. Systematic implications of male caudal morphology in ascaridoid nematode parasites. Systematic Parasitology 19: 215-228.

Garbin, L., S. Capasso, J. I. Diaz, A. Morgenthaler, A Millones, And G. Navone. 2014. Nuevo hospedador y registro geográfico de Contracaecum australe (Nematoda, Anisakidae) parasitando a Phalacrocorax gaimardi (Aves, Phalacrocoracidae) en costas del Atlántico Sudoccidental. Revista Argentina de Parasitología 2: 6-14.

Garbin, L., J. I. Diaz, F. Cremonte, and G. T. Navone. 2008. New anisakid species parasitizing the Imperial Cormorant Phalacrocorax atriceps from the North Patagonian coast, Argentina. Journal of Parasitology 94: 852-859.

Garbin, L., S. Mattiucci, M. Paoletti, D. GonzÁlez-Acuña, AND G. NASCETTI. 2011. Genetic and morphological evidences for the existence of a new species of Contracaecum (Nematoda: Anisakidae) parasite of Phalacrocorax brasilianus (Gmelin) from Chile and its genetic relationships with congeners from fish-eating birds. Journal of Parasitology 97:476-492.

Garbin, L. E. 2009. Taxonomía y evaluación de la especificidad hospedatoria de nematodos Anisákidos parásitos de aves marinas en el área de la Península Valdés, Chubut, Argentina. Ph.D. Dissertation. FCNyM, National University of $\mathrm{La}$ Plata, Buenos Aires, Argentina, 182 p.

Garbin, L. E., S. Mattiucci, M. Paoletti, J. I. Diaz, G. Nascettic, and G. T. Navone. 2013. Molecular identification of Contracaecum pelagicum (Nematoda: Anisakidae) from the anchovy Engraulis anchoita (Engraulidae) and fish-eating birds from Argentinian North Patagonian Sea, with larval morphological description. Parasitology International 62: 309-319.

Garbin, L. E., G. T. Navone, J. I. Diaz, and F. Cremonte. 2007. Further study of Contracaecum pelagicum (Nematoda: Anisakidae) in Spheniscus magellanicus (Aves: Spheniscidae) from Argentinean coasts. Journal of Parasitology 93: 143150

García-Borboroglu, P., And D. Boersma (eds.). 2015. Pingüinos: Historia natural y conservación. Vazquez Mazzini, Buenos Aires, Argentina, 368 p.

Gutiérrez, R. O. 1943. Sobre la morfología de una nueva especie de Contracaecum (Nematoda: Ascariroidea). Revista Brasileira de Biologia 3: 159-172.

Labriola, J., and D. M. Suriano. 1996. Parasitic nematodes of birds from De Monte Pond, Buenos Aires, Argentina. Boletín Chileno de Parasitología 51: 59-65.

Lewis R., T. C. O’Connell, M. Lewis, C. Campagna, and A. R. Hoelzel. 2006. Sex-specific foraging strategies and resource partitioning in the southern elephant seal (Mirounga leonina). Proceedings of the Royal Society of London Series BBiological Sciences 273: 2901-2907.

Mattiucci, S., R. Cianchi, G. Nascetti, L. Paggi, N. Sardella, J. Timi, S. C. Webb, R. Bastida, D. Rodriguez, and L. Bullini. 2003. Genetic evidence for two sibling species within Contracaecum ogmorhini Johnston and Mawson, 1941 (Nematoda: Anisakidae) from otariid seals of boreal and austral regions. Systematic Parasitology 54: 15-23.

Mattiucci, S., And G. Nascetti. 2008. Advances and trends in the molecular systematics of anisakid nematodes, with implications for their evolutionary ecology and host-parasite 
co-evolutionary processes. Advances in Parasitology 66: 47148.

Mattiucci, S., M. Paoletti, S. C. Webb, N. Sardella, J. T. Timi, B. Berland, and G. Nascetti. 2008b. Genetic relationships among species of Contracaecum Railliet and Henry, 1912 and Phocascaris Höst, 1932 (Nematoda: Anisakidae) from pinnipeds based on mitochondrial cox 2 sequences, and congruence with allozyme data. Parasite 15: 408-419.

Navone, G., J. A. Etchegoin, and F. Cremonte. 2000. Contracaecum multipapillatum (Nematoda: Anisakidae) from Egretta alba (Aves: Ardeidae), and comments on other species of this genus in Argentina. Journal of Parasitology 86: 807-810.

Nikolskiy, O. L. 1974. Contracaecum mirounga sp. n. (Nematoda: Anisakidae), a new nematode of the elephant seal from the Antarctic. Izvestiya Tikhookeanskogo Nauchno-Issledovatel'skogo Instituta Rybnogo Khozyaystva i Okeanografii 83: 107-109.

Novo Borges, J., H. L. Carneiro Santos, M. L. Brandão, E. G. Nunes dos Santos, D. Ferreira de Miranda, D. De Almeida
Balthazar, J. L. Luque, and C. Portes-Santos. 2014. Molecular and morphological characterization of Contracaecum pelagicum (Nematoda) parasitizing Spheniscus magellanicus (Chordata) from Brazilian Waters. Revista Brasileira de Parasitologia Veterinária 23: 74-79.

Portes-Santos, C. P. 1984. Um nematodeo parasito de pinguim Spheniscus magellanicus (Forster) (Ascaridoidea: Anisakidae). Memorias do Instituto Oswaldo Cruz 79: 233-237.

Rohde, K. 2005. Marine parasitology. CSIRO Publishing, Collingwood, Autralia, 590 p.

Schuurmans Sterkhoven, J. H. 1951. Nematodos parasitarios de anfibios, pájaros y mamíferos de la República Argentina. Acta Zoologica Lilloana 10: 315-400.

Silva, R. J., T. F. Raso, P. J. Faria, and F. P. Campos. 2005. Occurrence of Contracaecum pelagicum Johnston \& Mawson 1942 (Nematoda, Anisakidae) in Sula leucogaster Boddaert 1783 (Pelecaniformes, Sulidae). Arquivo Brasileiro de Medicina Veterinária e Zootecnia 57: 565-567. 